\title{
Private Enterprise and the Sustainable Community Economic Development in Bangladesh A Case Study on the PRAN-RFL Group
}

\author{
Mohamed K Haq ${ }^{1}$, Saleh Md Arman ${ }^{2}$, Farzana Nazera ${ }^{3}$ \\ ${ }^{I}$ Department of Management, University of Dhaka, Bangladesh \\ ${ }^{2}$ MSc in Sustainable Development, Uppsala University, RP Shaha University, Bangladesh \\ ${ }^{3}$ Ph.D. Student in Management, Limkokwing University of Creative Technology, Malaysia \\ DOI: https://dx.doi.org/10.47772/IJRISS.2021.5402
}

\begin{abstract}
Community Economic Development (CED) practice in Bangladesh is vital in ensuring the sustainability of the community and economy of Bangladesh and it contributes to the creation and maintenance of economic, social, ecological, human, political, and cultural capitals of communities in a sustainable and progressive manner. Existing literature in Bangladesh perspective mostly focuses on NGO contributions. However, local large conglomerates have contributions in this aspect and the study would like to tap on the research gap by conducting an intensive case study on PRAN-RFL Group (PRG), one of the largest conglomerates in Bangladesh and South East Asia. The case study provided a theoretical background of the business profile of the PRG. Researchers collected data from the organizations about their CED contributions to different areas ofBangladesh even in the ongoing COVID19 time. PRG's contributions to those remote areas were found significant and valuable to make the society sustainable and resilient. For this reason, the partnership between the PRG and the community (individual entrepreneur) was remarkable. The study concluded that PRG's contribution to the CED practices set examples of their competitors of Bangladesh in various CED practices. The study recommended further quantitative analysis in assessing community farmers and reverse migration in this aspect.
\end{abstract}

Keywords: Sustainable Community Economic Development, PRAN-RFL Group (PRG), Sustainable Development Goals (SDGs).

\section{INTRODUCTION}

$\mathrm{T}$ The significance of Sustainable Community Economic Development (CED) practices in Bangladesh has a long history and the contribution to different entities (e.g., NGOs and Business Organizations) are remarkable (Islam, 2016).It is a multidimensional concept for which corporate social action can contribute to the creation and maintenance of economic, social, ecological, human, political, and cultural capitals of communities in a sustainable and progressive manner (Idemudia, 2007; Muthuri et al., 2012). Business Corporations of Bangladesh do not operate in closed systems but in open systems where the community stakeholders of Bangladesh are becoming more aware and conscious of their rights and where they expect companies to embrace expanded social responsibilities and to contribute to complex societal problems in a particular governance arena. Three interrelated, interconnected and intertwined goals of sustainable community economic development (improved socioeconomic and cultural conditions of the host communities, capacity building and self-help in host communities, and community empowerment) are vital in this aspect (ibid).The PRAN-RFL Group, one of the largest conglomerates of Bangladesh and the South East Asia, has remarkable contributions to the field of CED. They do their CED contributions mainly through contract farming where they engage in business community partnership model (Haq, Arman and Nazera, 2021; PRANRFL Group, 2017).

\subsection{Background of the Research Problem}

The establishment of PRAN-RFL Group, back in 1981, was based on the vision of poverty alleviation and providing products that enhance health, nutrition, and well-being of the society. Interestingly, these points have constantly been addressed by different CED researchers in their contributions notably Boothroyd and Davis (1993), Weissbourd and Bodini (2005), Shaffer, Deller and Marcouiller (2006), Phillips and Pittman (2009), Muthuri et al., (2012) and so on. Along the way, the contribution the PRG to increase rural livelihood in Bangladesh with improving the standard of living by employment generation, which are also related to the CED as well. The PRG is keenly aware of its responsibility for society and this awareness is reflected in its activities by engaging continuously in CED. Their contract farming activities are key instruments in this aspect, which gives them competitive advantage by ensuring a large countrywide network of partnership with individual entrepreneurs which considers a remarkable economic and community development to the society at large. The PRG are aware of achieving sustainable development goals within 2030 and their activities are crucial not only related to satisfying Sustainable Development Goals (SDG) (United Nation, 2015) but also respond vigorously and promptly against the ongoing COVID19 Pandemic. 


\subsection{Research Gap}

CED contributions as a research topic in Bangladesh perspective is quite new and most of the published papers available in different journals are focusing only on NGO contribution. We have a published work in 2021 on CED contribution through contract farming in poultry industry of the country. There we identified some future research opportunities about business organization(s)' contribution in CED at large. In this paper, we would like to fill this gap by conducting a case study research on PRAN Group and their contribution to the CED of Bangladesh by evaluating their association with covering different sustainable development goals and responding the covid19 pandemic to ensure better economy and community.

\subsection{Problem Statement}

As a large conglomerate of Bangladesh, PRAN-RFL Group, despite its Corporate Social Responsibility (CSR), has been, engaging various CED activities in Bangladesh. As per our own observation, many underprivileged societies in different regions of Bangladesh are now economically growing gradually. According to our observation of the Northern territory of Bangladesh, many contract farmers who are working independently for the PRG are enjoying a good life by fulfilling their basic needs properly. Different SDGs are remarkable and the study would like to address on those. These contributions are exemplary and could be set as a guideline to many countries which are quite similar to Bangladesh in terms of economic classification.

\subsection{Aim, Scope and Delimitations of the Study}

The research aims to make a case study on PRAN-RFL Group about their CED contributions in different parts of Bangladesh. We collected CED contributory activities from the respective people of the business group and presented in a rhetoric form in order to make a research output for giving an idea about how the PRG is significant in assuring the sustainability of community and economy of Bangladesh. The scope of the study is only on the information received from the concerned people of the PRG who seek anonymity.The study limits itself to assess on that information and no quantitative analysis had conducted.

\subsection{Objectives of the Study and Research Questions}

The objective of the study is to assess the sustainable CED contribution by the PRG in different areas of Bangladesh in the light of covering different SDG aspects.

In line with this objective, the following research questions need to be addressed:

$R Q$ 1: In what ways PRAN-RFL Group contributes to the sustainable community and economic development in Bangladesh?
RQ2: How are these contributions aligned with different Sustainable Development Goals (SDGs)?

\subsection{Originality of the Study}

There is no published authentic research paper on the PRG's contribution to the sustainable Community Economic Development by satisfying different SDGs simultaneously and responding COVID19 pandemic to ensure better community and economic climate. This original paper is an exploratory in nature which would pave the way of conducting many future researches.

\section{METHOD}

The research considers PRAN-RFL Group according to their own convenience in terms of collecting data on CED contribution from the key officials. There is no published CED contributions of the PRG. So the researchers conveniently collected required information from them who seek their anonymity. The study collected published information from the PRG website in order to get their company profile and societal contribution. Researchers use Google scholars search engine and Snowball technique for finding out research papers.

\subsection{Ethical Consideration}

Researchers ensure the anonymity of the officials of the PRG who provided the required information for conducting the study.

\section{THEORY}

\subsection{Concept of Community Economic Development}

Community economic development (CED) is a discipline of multifaceted approach which covers all sorts of relevant community and economic aspects and promotes the development as a whole. Renowned scholars from different corners of the world have contributed in this area to make it more updated and upgraded as the time passed. Boothroyd and Davis (1993) coined the concept of CED in their publication which mention about such a discipline which discussed about growth, structural change and community relationships. They mention CED as a human centric system of human activity directed to meeting human wants that is determined by deliberate allocations of scarce resources based on four important assumptions: i) the local economy extends beyond marketplace transactions through non-cash transaction in order to promote societal wellbeing, ii) increase local control, iii) local and diversified ownership, local resource control, diversification of exports, and import replacement are the keys of monetary flow of the community, and iv) deliberate restructuring of the local economy by people of the concerned community (ibid).

Weissbourd and Bodini (2005) mentioned four aspects of CED based on market driven approach: i) Proper identification of poverty and creation of wealth, ii) Asset 
investment is the approach to resolve poverty of the society, iii) Market is the mechanism of asset investment, iv) market activity and wealth maximization are positively correlated.

According to Shaffer, Deller and Marcouiller (2006), CED is a combination of community development and economic development and an interdisciplinary and holistic approach to ensure the economic sustainability of the people of the community through 6 paradigms: space, decision making, rules/ institutions, resources, society/culture and markets. As per their insights, community economic development occurs when people in a community analyze the economic conditions of that community, determine its economic needs and unfulfilled opportunities, decide what can be done to improve economic conditions in that community, and then move to achieve agreed-upon economic goals and objectives.

Phillips and Pittman (2009) considered CED as a combination of Community Development and Economic Development and the purpose of community development is to produce assets and the purpose of economic development is to mobilize those assets. They mentioned four types of capitals which are the keys to community economic development: human, financial, physical and social capitals.

\subsection{Community Economic Development in Bangladesh}

The practice of Community Economic Development has mainly been found through contract farming practice, which plays important roles in the community development of developing countries like Bangladesh in the rural areas in terms of assuring food security, employment generation and family participation in income generation (Haq, Arman and Nazera, 2021; Rahman et al., 2020; Islam and Jabbar, 2005). In order to develop a sustainable community economic development through promoting contract farming, it is crucial to study the discussion of SDG interactions and Haq, Arman and Nazera (2021) mentioned the interactions to poultry industry of Bangladesh with four Sustainable Development Goals which are: SDG 1: No Poverty, SDG 2: Zero Hunger, SDG 3: Gender Equality and SDG 4: Decent Work and Economic Growth. These contract farming practices enable farmers of Bangladesh to earn livelihood essential for survival with family to cover basic needs, enjoy technical knowhow, access to the key resources, cooperation with contractors which eventually alleviate them from poverty (ibid).

\section{PROFILE OF PRAN-RFL GROUP}

PRAN-RFL Group is the brain child of Late Amjad Khan Chowdhury, a retired army general started his business venture after leaving the army career. The PRG was born in 1981. An efficacious period of 5 years led to the diversification of PRAN's operations into agriculture of Bangladesh in 1986 through contract farming, with the coordination of AMCL, (Agriculture Marketing Company Limited).PRAN further surfaced its place in the industry through a food processing plant at Ghorashal in 1992. Coming through this period of endeavor, the PRG has now established itself as one of the top manufacturing companies and has set the grounds for development for any potentialities.

Improving livelihood is their vision and their mission is to generate employment and earn dignity \& self-respect for their compatriots to remove the curse of poverty (SDG 1) and hunger (SDG 2). Their vision and mission are quite aligned with the concept of sustainable CED activities by touching the first two sustainable development goals (Neshovski, 2018). They set an industry-wide benchmark in its home country Bangladesh through its continuous contributions to the economy. The talent management within the corporation has allowed its excellent workforce to work together in building an organization that believes in providing equal opportunity for everyone. Also, the PRG acknowledges all the complaints and suggestions given from every single level of the organization. Its corporate culture is based on maintaining professional integrity. The PRG rewards competence and the workflow is deadline oriented.

PRAN-RFL Group is now divided into two groups namely PRAN Group and RFL Group. PRAN Group is pro-food processing and RFL Group is not food oriented. Today, PRAN is the largest food processing company in Bangladesh started reaching out international market since 1997 with canned pineapple to France which eventually increased into currently 148 countries of all continents: from South East Asia, Middle East, Far East and Africa, Australia, Europe, USA and Canada. The exponential growth of export earnings for the group hit $\$ 150$ million in 2016 which were $\$ 51$ million in 2011 achieving 183 percent growth in 5 years. Through stronger presence in the international market, they strive to equal our local and global sales which are at 1:4 ratio currently with total sales revenue of $\$ 500$ million. They have a strong market base in India accounting one-third of our global sales following with the Gulf and African countries as the biggest buyer of their products. Through capital transfer, they intend to strengthen their base in South East Asia region further.

They have a long list of products in the food sector, which are as follows:

\begin{tabular}{|c|c|}
\hline Categories & $\begin{array}{c}\text { Sub Category with number of } \\
\text { brands in bracket }\end{array}$ \\
\hline Beverages & $\begin{array}{c}\text { Carbonated Soft Drinks (6) } \\
\text { Drinking Water (1) } \\
\text { Flavoured Drink (2) }\end{array}$ \\
(PRAN Group & Fruit Drink (6) \\
Beverages, 2021) & Health Drink (1) \\
& Hot Beverages (1) \\
Juice (1) \\
Biscuit and Bakery & Malt Drinks (2) \\
(PRAN Biscuit and & Biscuits (6) \\
Bakery, 2021) & Bread (5) \\
Bun (6) \\
Culinary & Cake (6) \\
(PRAN Culinary, 2021) & Cooking Oil (5) \\
\hline
\end{tabular}




\begin{tabular}{|c|c|}
\hline & $\begin{array}{c}\text { Ready to eat (6) } \\
\text { Rice and Pulses (6) } \\
\text { Sauce (2) } \\
\text { Soup (1) } \\
\text { Spiced and Herbs (6) }\end{array}$ \\
\hline $\begin{array}{c}\text { Dairy } \\
\text { (PRAN Group Dairy, } \\
\text { 2021) }\end{array}$ & $\begin{array}{c}\text { Butter (1) } \\
\text { Cheese (2) } \\
\text { Fresh Milk (3) } \\
\text { Ghee (1) } \\
\text { Powder Milk (4) } \\
\text { Value added Milk (6) } \\
\text { Yoghurt (4) } \\
\end{array}$ \\
\hline $\begin{array}{c}\text { Frozen Foods } \\
\text { (PRAN Group Frozen } \\
\text { Foods, 2021) } \\
\end{array}$ & Frozen Foods (6) \\
\hline $\begin{array}{c}\text { Snacks } \\
\text { (PRAN Group Snacks, } \\
\text { 2021) }\end{array}$ & $\begin{array}{l}\text { Chips and Crackers (6) } \\
\text { Local Ethnic Snacks (6) } \\
\text { Noodles and Pasta (4) } \\
\text { Nuts and Pulses (6) } \\
\text { Papar (1) }\end{array}$ \\
\hline & $\begin{array}{c}\text { Bean (1) } \\
\text { Chocolate Bar (4) } \\
\text { Deposited Candy (3) } \\
\text { Gum (6) } \\
\text { Hard Boiled Candy (4) } \\
\text { Liquid Chocolate (2) } \\
\text { Lollypop (5) } \\
\text { Soft Chewing Candy (5) } \\
\text { Spread Chocolate (1) } \\
\text { Toffee (5) } \\
\text { Wafer (3) }\end{array}$ \\
\hline
\end{tabular}

Table 1 Food Products of PRAN Group

\section{RESULT AND DISCUSSION}

\subsection{Sustainable CED Contribution of PRAN Group in the Light of Sustainable Development Goals:}

The establishment of PRAN was based on the vision of providing products that enhance health, nutrition, and wellbeing of society. Along the way, it has contributed to increased rural livelihood in its domestic country, improvement in the standard of living, a boost of the national foreign reserve and employment generation. PRAN is keenly aware of its responsibility for society and this awareness is reflected in its activities. PRAN Food's principal source of raw food material is contract farming. It greatly contributes to an economic improvement of rural livelihood by means of employment generation and overall improvement of the condition of the rural localities. Growers are provided with quality inputs (seeds, fertilizers, pesticides), improved and advanced cultivation techniques, access to finance, crop insurance, advanced storage and collection system and access to the international market for their products.

PRAN believes in providing benefits that are sustainable in the long-run. The provision of tools, knowledge, and finance nurture self-sufficiency. Also, PRAN supports the farmers working by providing them with financial assistance on every level. PRAN's contributes to government expenditure in education, infrastructure development, public employment generation and cash transfer under safety nets. It is also one of the largest corporate taxpayers in its domestic country.
PRAN's CED activities are closely associated with different SDGs and based on achieving those SDGs through sustainable CED activities PRAN is remarkable in Bangladesh perspective (United Nations, 2015). Based on the data collection about CED contributions of PRAN Group by the researchers are presented as follows:

a) Free medical camps of reputed healthcare consultants in different areas are regularly arranged at Amjad Khan Chowdhury Memorial Hospital in Natore, Bangladesh which is named after their founder. Apart from national days (e.g., The Victory Day of Bangladesh), they arrange it very frequently.

b) Also, PRAN group establish Sun Healthcare Foundation in Hobiganj, Bangladesh to provide diagnostic and consultation service at the lowest possible cost. Sun Healthcare has also another establishment in the capital city Dhaka of Bangladesh.

c) Dengue is a common epidemic in Bangladesh, which recurrent in every year. PRAN arrange free medical checkup for Dengue patients.

d) PRAN extend their hands to fight against the ongoing COVID 19 pandemic by providing healthcare facilities to their community farmers, employees and vulnerable people.

Setting up a good healthcare service like Amjad Khan Chowdhury Memorial Hospital and Sun Healthcare Foundation in remote areas of Bangladesh is a good example of complying with SDG 3: Health and Wellbeing (Neshovski, 2018; United Nations, 2015).

e) Through establishing PRAN RFL Public School (PRPS) in 2014 in Ghorashal, Narshingdi, Bangladesh and Hobiganj Industrial Park School (HIP) (the largest industrial parks of the PRG). Besides these, the PRG has been contributed both financial and non-financial aid to the education sectors in the remote communities of Bangladesh. This complies with SDG 4: Education. They provide all sort of modern amenities for education which is quite remarkable in the outside of the capital of Bangla Medium schools. As of 2020, they had 1409 students in different levels of these two schools and number of teachers were 59. They have lots of accolades till date, notably PRPS won the Best Primary School Award in Narshingdi and International School Award by the British Council. In addition to providing all sorts of modern education facilities to all students, teachers get lots of facilities along with their basic salary, for example, in house training, accommodation facility, healthcare facility, subsidized food facility, insurance facility, GDPS and so on which are not, as much, available for the teachers of other private schools in Bangladesh. 
f) Apart from their own established schools, they pay BDT 102454 as guest teacher salary in Ghorashal Pilot High School, Narshingdi, Bangladesh.

g) Their employment generation through contract farming with over 10000 contract farmers of Bangladesh. In each step: farming, processing and marketing, PRAN have put an enormous contribution by serving small farmers in fertilizer, seeds and pesticides motivating farmers to produce more crops organizing farmers to grow specific crops marketing products for profit setting up production facilities to add value.

h) Besides, PRAN Dairy hub alone sets an example of community dairy development project of connected over 19000 farmers of 87 villages in 18 districts of North Bengal. Under this hub, PRAN facilitates:

Dairy farmer organization in different activities: Milk Hygiene, Cow comfort, Dairy Shed management, Feeding, Disease prevention \& Controlling.

Milk Production supporting activities: Cattle Breed up gradation through imported semen, Concentrate Cattle Feed production and Supply to dairy farmers, Grass seeds distribution to farmers and Grass cultivation.

Healthcare of cattle: Vaccination and fodder development, De warming, Vet. Treatment Service, Quality Vet. Medicine supply. Technical Support at different levels of production, distribution and delivery

In addition to alleviate poverty (SDG 1) and mitigating hunger problem (SDG 2) of the community and economy at large, these activities also generate employment of the remote areas of Bangladesh which would also help re-employment generation in the post COVID19 era (SDG 8: Decent Work and Economic Growth).

Under SDG 11: Sustainable City and Community, PRAN Group provide assistance in road, culvert, bridge development and repair. They set road dividers. They also dig canals which prevents the community from unwanted water logging.

i) PRAN group supports religious institutions by sponsoring required amenities. For example, they establish KamartekJame Masjid, Narshingdi and provide staff salary related to that Masjid. In addition to this, they pay substantial amount of donations in different orphanage to ensure a better living to the helpless orphans.

j) PRAN provide vehicle support to law enforcement agencies as well to improve their surveillance. They donate BDT 2000 each month to improve Ghorashal Bazar Traffic, Narshingdi, Bangladesh.

k) PRAN regularly arrange "Mosquito Killing Drives" in the adjacent areas of their industrial parks to fight against Dengue fever epidemic and other mosquito borne diseases including COVID-19 prevention measures.

1) PRAN develop infrastructures to provide clean water and sanitation facility to the community, especially in the North Bengal districts (SDG 6: Clean Water and Sanitation).

m) Floods and storms are common phenomenon in Bangladesh, which impose tremendous challenges in terms of disaster management and resilience. PRAN undertakes strong steps in tackling those debacles by providing huge reliefs in the shortest possible time to the victims. PRAN distribute free masks, sanitizers in different areas of Bangladesh to curb COVID19 pandemic. These activities are in line with $S D G$ 13: Climate Action.

n) PRAN is conscious about environment by establishing three Effluent Treatment Plants in their industrial areas (capacities are: 175000ltr/day, $100000 \mathrm{ltr} /$ day and 500001tr/day) which prevents water pollution.They have modern amenities in energy conservation and preservation. They recycle plastics, collecting and reproducing products from scraps and waste, upcycling it by creating different products to ensure circular economy in Bangladesh. PRAN plant lots of local trees to ensure biodiversity of the community. Their activities are significant in mitigating climate risks. By contributing in SDG 13: Climate Action, SDG 14: Life Below Water and SDG 15: Life on Land PRAN complies with a great commitment to the environment issues and circular economy.

o) Besides re-employment generation for reverse migrated workers in rural areas of Bangladesh due to COVID19 (SDG 8), PRAN Group run a special campaign entitled "Pashe Achi Bangladesh (English: Bangladesh, We are With You)" as a part of disaster response and resilience (SDG 13: Climate Actions) and partnerships with different community associations like hospitals, law enforcement agencies for donating health protective amenites (SDG 17: Partnerships). Under the campaign, they have been running the following activities till February 2021:

Under this campaign, PRAN-RFL Group has done the following relief activities (see Table 1) 


\begin{tabular}{|c|c|c|}
\hline No & Item & Quantity \\
\hline 1 & Rice & $80000 \mathrm{~kg}$ \\
\hline 2 & Salt & $2000 \mathrm{~kg}$ \\
\hline 3 & Dal & $2000 \mathrm{~kg}$ \\
\hline 4 & Muri, Chira and Roti & 9000 packets \\
\hline 5 & Mr. Noodles & 18000 packets \\
\hline 6 & PRAN UHT Milk & 35000 packets \\
\hline 7 & PRAN Juice & 35000 bottles \\
\hline 8 & PRAN Soyabean Oil & 12000 bottles \\
\hline 9 & PRAN BUN & 116000 packets \\
\hline 10 & PRAN Snack Bar & 116000 packets \\
\hline 11 & PRAN Toast & 6000 packets \\
\hline 12 & PRAN Cake & 6000 packets \\
\hline 13 & PRAN Biscuits & 70000 packets \\
\hline
\end{tabular}

Table 1: $\quad$ PRAN Products

- Under this campaign, 50000 families have got relief support

- Approximately 250000 people has been benefited.

- PRAN Group organized these relief facilities in 42 districts of Bangladesh.

- They supported local authorities and law enforcement agencies in distributing reliefs.

- They launched the social awareness campaigns in TV, Online and road.

- They established 120 bed Corona Isolation unit at Amjad Khan Chowdhury Memorial Hospital, Natore, Bangladesh.

- They provided 10 Covid-19 sample collection booths to Dhaka Medical College, Police Hospital, Bhola Sadar Hospital, Shahid Sohrawardi Medical college (Medford Hospital).

- They exclusively provided health and safety products to the RAB and Bangladesh Police. Till February 2021, they donate: 500 PPEs, 72500 pieces surgical masks,5000 pieces hand gloves, 30000 pieces antibacterial soaps, 500 pieces face shields and 2000 pieces hand sanitizers.

\section{LIMITATIONS OF THE STUDY AND DIRECTION OF THE FUTURE RESEARCH}

There are no published documents where it is written about PRAN's contribution in the sustainable CED. There is very little information about societal contribution. However, it's futile in terms of conducting research. Researchers collected information from the respective people of the group as much as they can. Not with standing, the concerned people requested for anonymity. Also, the study conducted the SDG associations with different CED activities by PRAN group based on the information provided by the PRAN officials and own observation, however SDG interaction would be more rigorous and fruitful if the information has been available to them.

Future directions of the research could be quantitative analyses of changing livelihood of the contract farmers by comparing before and after engaging contract farming with PRAN group. The community members, that are individual farmers' response, would be a good follow up study of this paper and the researchers would like to conduct those as well. Also, there would be a possible research opportunity in reemployment generation in the post COVID19 era by PRAN group focusing on reverse migrated workforce.

\section{CONCLUDING REMARKS}

The study concluded that, PRAN-RFL Group has a diverse range of Community Economic Development activities in Bangladesh and those CED activities are inseparable in achieving Sustainable Development Goals (SDGs) within 2030 by Bangladesh. So, in the chronicles of the sustainability of the community and economy of Bangladesh. Additionally, their contribution in responding the ongoing COVID19 pandemic is significant. PRAN set a good benchmark to their competitors which are good for the betterment of the country at large to ensure sustainable CED of Bangladesh. This paper would facilitate a good information source of conducting future research in CED contribution by any Bangladeshi conglomerate which would be ideal to conduct relevant studies in upcoming future.

\section{ACKNOWLEDGEMENT}

Researchers would like to thank the Chairman, directors, officials of different departments and key persons at four industrial parks of PRAN-RFL Group.

\section{REFERENCES}

[1] Boothroyd and Davis, 1993 - Community Economic Development Three Approaches.pdf. Available at: $<$ https://www.webpages.uidaho.edu/classbiop/pdf/tammi10/Boothroyd\&Davis_CommEconDev.pdf> [Accessed 7 March, 2021].

[2] Haq, M. K., Arman, S.M., and Nazera, F., 2021. How Contract Farming in Poultry Industry Contribute to the Sustainable Community Economic Development of Bangladesh: A Literature Review. Journal of University of Shanghai for Science and Technology, 23(1).

[3] Idemudia, U. (2007). Community perceptions and expectations: Reinventing the wheels of corporate socialresponsibility practices in the Nigerian oil industry. Business and Society Review, 112(3), 369-405.

[4] Islam, M. R. (2016). Non-governmental organizations and community development in Bangladesh International Social Work, 60(2), 479-493. https://doi.org/10.1177/0020872815574133.

[5] Islam, S M F and Jabbar, M A (2005). Smallholder poultry model for poverty alleviation in Bangladesh: a review of evidence on impact. Livestock Research for Rural Development. Volume 17, Article\#112. Retrieved February 26, 2021, from http://www.lrrd.org/lrrd17/10/fakh17112.htm

[6] Lee, L. (2011). Business-community partnerships: understanding the nature of partnership. Corporate Governance: The International Journal of Business in Society, 11(1), 29-40. https://doi.org/10.1108/14720701111108826 
[7] Muthuri, J. N., Moon, J., \&Idemudia, U. (2012). Corporate Innovation and Sustainable Community Development in Developing Countries. Business \& Society, 51(3), 355-381. https://doi.org/10.1177/0007650312446441

[8] Neshovski, R. (2018). United Nations Sustainable Development. United Nations Sustainable Development; United Nations. https://www.un.org/sustainabledevelopment/

[9] Pran Biscuit and Bakery. (2021). Biscuit and Bakery. PRAN Foods Ltd Malaysia. https://www.pranfoods.net/my/brands/biscuit-and-bakery

[10] PRAN Culinary. (2021, March 8). Culinary. PRAN Foods Ltd Malaysia. https://www.pranfoods.net/my/brands/culinary

[11] Pran Group Beverages. (2021). Beverages. PRAN Foods Ltd Malaysia. https://www.pranfoods.net/my/brands/beverages

[12] Pran Group Dairy. (2021). Dairy. PRAN Foods Ltd Malaysia. https://www.pranfoods.net/my/brands/dairy

[13] Pran Group Frozen Foods. (2021, March 8). Frozen Foods. PRAN Foods Ltd Malaysia. https://www.pranfoods.net/my/brands/frozenfoods

[14] Pran Group Snacks. (2021, March 8). Snacks. PRAN Foods Ltd Malaysia. https://www.pranfoods.net/my/brands/snacks
[15] Pran Group Sugar Confectionary. (2021, March 8). Sugar Confectionery. PRAN Foods Ltd Malaysia. https://www.pranfoods.net/my/brands/sugar-confectionery

[16] PRAN Group. (2017, April 16). PRAN in Society. PRAN Foods Ltd Malaysia. https://www.pranfoods.net/my/about/pran-society.

[17] Rahman, K.M.M., Hossain, Md.J. and Rana, M.S., 2020. Livestock And Poultry Rearing By

[18] Smallholder Farmers InHaor Areas In Bangladesh: Impact On Food Security And Poverty Alleviation: The Bangladesh Journal of Agricultural Economics, [online] 41(1), pp.73-86. Available at: $\langle$ http://bjae.bau.edu.bd/home/article/view/50>.

[19] Shaffer, R., Deller, S. and Marcouiller, D., 2006. Rethinking Community Economic Development. Economic Development Quarterly, 20(1), pp.59-74.

[20] United Nations. (2015). \#Envision2030: 17 goals to transform the world for persons with disabilities | United Nations Enable. Un.org; United Nations. https://www.un.org/development/desa/disabilities/envision2030.ht $\mathrm{ml}$

[21] WeissbourdR. and Bodini, R., 2005. MARKET-BASED COMMUNITY ECONOMIC DEVELOPMENT.pdf. Available at: $<$ http://rw-ventures.com/wp-content/uploads/2017/01/MarketBased-Development.pdf $>$ [Accessed 6 March, 2021]. 